Бобровнік Юрій Вікторович кандидат історичних наук, викладач кафедри публічного управління та адміністрування ДВНЗ «ПереяславХмельницький ДПУ імені Григорія Сковороди», вул. Сухомлинського 34, к. 908, м. Переяслав, 08401, тел.: (093) 335-78-86, e-mail: neasmo@ gmail.com, https://orcid.org/0000-0003-1410-5308

\title{
РЕФОРМА ОРГАНІВ МІСЦЕВОГО САМОВРЯДУВАННЯ В 2014-2020 РОКАХ. ДЕЦЕНТРАЛІЗАЦІЯ ВЛАДИ
}

Анотація. У статті розглядається реформа органів місцевого самоврядування в Україні, що проводилася в 2014 - 2020 роках, яка передбачала утворення ефективного місцевого самоврядування шляхом утворення об'єднань територіальних громад на зразок сучасних європейських практик. Реформа передбачала децентралізацію влади в Україні, передачу як обов'язків так і відповідних фінансових ресурсів від центру на місця. Таким чином, реформатори намагалися наблизити владу до жителі громад. Автором здійснено спробу висвітлити процес децентралізації розкриваючи та аналізуючи офіційно декларовані принципи об'єднання територіальних громад i фактично того, що відбувалося на практиці. У статті акцентовано увагу на певні перекоси в процесі реалізації реформи, зокрема на Київщині, які існували до 01 січня 2021 року, і були утворені внаслідок відхилення від вимог медичних рекомендацій, щодо спроможності громад. Перша головна проблема яка виникла, це не можливість новоутвореними громадами забезпечувати отримані власні повноваження внаслідок відсутності прямого бюджетного фінансування. Блокуванням їх фінансових надходжень, що передбачені реформою. Як наслідок кілька річне існування юридично утворених територіальних громад, після проведення перших місцевих виборів, без належного законодавчо визначеного фінансування їх діяльності.

Розкрито головні проблеми новоутворених територіальних громад, зокрема, відсутність необхідних фахівців, особливо у новоутворених сільських об'єднаних територіальних громадах, неефективне використання бюджетних коштів.

Висвітлено процес укрупнення районів та утворення нового адміністративно територіального устрою в Україні, що поклав край існуванню радянського адміністративно-територіального устрою, що існував і роки незалежності української держави.

3'ясовано автором основні цілі та завдання реформи децентралізації влади в Україні та визначено перспективу подальшого дослідження процесів децентралізації в Україні. 
Ключові слова: реформа, органи місцевого самоврядування, децентралізація, децентралізація влади, об'єднана територіальна громада.

Bobrovnik Yuriy Viktorovych Candidate of Historical Sciences, Lecturer of the Department of Public Administration and Administration of PereyaslavKhmelnytsky State Pedagogical University named after Hryhoriy Skovoroda, Sukhomlynskoho St. 34, room 908, Pereyaslav, 08401, tel.: (093) 335-78-86, email: neasmo@gmail.com, https://orcid.org/0000-0003-1410-5308

\section{REFORM OF LOCAL GOVERNMENT BODIES IN 2014-2020. DECENTRALIZATION OF POWER}

Abstract. The article examines the reform of local self-government in Ukraine, which was carried out in 2014-2020 and provided for the formation of effective local self-government through the formatting associations of territorial communities on the model of modern European practices. The reform provided for the decentralization of power in Ukraine, the transfer of both responsibilities and appropriate financial resources from the center to the field. Thus, the reformers tried to bring power closer to the people of the community. The author tries to cover the process of decentralization by revealing and analyzing the officially declared principles of unification territorial communities and in fact what was happening in practice. The article focuses on certain distortions in the process of reform, in particular in Kyiv region, which existed until January 1, 2021, and were formed because of deviations from the requirements of medical recommendations on the capacity of communities. The first major problem that has arisen is the inability of newly formed communities to secure their own powers due to the lack of direct budget funding. By blocking their financial revenues provided by the reform. As a result, several years of existence legally formed territorial communities, after the first local elections, without proper legally defined funding for their activities.

The main problems of the newly formed territorial communities are revealed, in particular, the lack of necessary specialists, especially in the newly formed rural united territorial communities, inefficient use of budget funds.

The process of consolidation of districts and the formation of a new administrative-territorial system in Ukraine, which put an end to the existence of the Soviet administrative-territorial system, and existed during the years of independence of the Ukrainian state, is covered.

The author clarifies the main goals and objectives of the decentralization reform in Ukraine and identifies the prospects for further study of decentralization processes in Ukraine.

Keywords: reform, local self-government bodies, decentralization, decentralization of power, united territorial community.

Постановка проблеми. Після Революції Гідності, виборів нового Президента, 25 травня 2014 року, в Україні було започатковано низку 
реформ, реалізація яких сприяла отриманню Україною без візу із країнами Європейського Союзу. Революційні події в Україні 2004 року та 2013-2014 роках, вказували на неефективність чинної адміністративної системи державного управління, слабкість розвитку органів місцевого самоврядування та їх залежності від центральних органів влади.

Процес децентралізації влади розпочато 2014 року 3 прийняттям Концепції реформи місцевого самоврядування та територіальної організації влади в Україні від 01 квітня 2014 року, законів України «Про співробітництво територіальних громад» від 17 червня 2014 року, «Про добровільне об'єднання територіальних громад» від 05 лютого 2015 року та змін до Бюджетного i Податкового кодексів - щодо фінансової децентралізації. Експерти, голови новоутворених громад та окремі народні депутати України, вважали, що реформа децентралізації одна із найуспішніших, що була реалізована в незалежній Україні. Проте існувало подання до Конституційного суду України від групи народних депутатів України 3 проханням визнати реформу не конституційною. Відповідно скасувати всі здобутки процесу децентралізації влади в Україні.

Аналіз останніх досліджень i публікацій. Процеси пов'язані із децентралізацією досліджували вчені iз різних галузей науки, також висвітлювали хід реформи громадяни, які особисто брали участь у іï реалізації.

До першої групи відносимо тих дослідників, що мають коло своїх наукових інтересів пов'язаних із процесами державного управління та розвитку органів місцевого самоврядування. Загалом децентралізацію влади як сучасний процес та перспективи його розвитку досліджували науковці I.В. Гнидюк та Ю.І. Гороховська [1, с. 108-111]. Проблему децентралізації в реформуванні місцевого самоврядування в Україні в розрізі державного управління у своїй статті вивчала Т. Тарасенко [2, с 277- 286].

Другу групу дослідників становлять правники. Децентралізацію та реформу місцевого самоврядування в контексті передачі повноважень висвітлювали у своїй статті Л. Василенко, М. Добровінський [3, с. 123- 126]. В. С. Сгорова 3 юридичного аспекту висвітлила процес децентралізації у науковій розвідці, зосередившись на загальній характеристиці реформи, передачі повноважень та важелів прийняття рішень від центру до регіонів [4, с. 66- 69]. Л.О. Нікітенко, В.І. Кондратенко через призму права в науковій статті, розглядали питання децентралізації влади в контексті поточного реформування місцевого самоврядування в Україні. Увага авторів стосувалася реалізації Концепції реформи місцевого самоврядування та територіальної організації влади в Україні, а також напрацюваннях першого етапу здійснення Концепції та перспективах подальшого розвитку законодавства. Авторами розглянуто нормативно-правову базу, розроблену в рамках реформування. Зроблено висновок, що процес децентралізації потребує комплексної роботи компетентних осіб та усвідомлення територіальними громадами своїх можливостей на місцях [5, с. 2015: 132-136].

I. Юркевич проаналізувавши теоретичні та практичні аспекти 
децентралізації, як фундаменту в утвердженні демократії в Україні. Досліджувала законодавчу базу для проведення реформи 3 децентралізації влади. Здійснила спробу висвітлити проблеми децентралізації в Україні та визначити переваги децентралізованого управління та можливі ризики [6, с. 100-104].

Окремо варто відмітити навчальний посібник колективу авторів А.П. Лелеченко, О.І. Васильєва, В.С. Куйбіда., А.Ф. Ткачук. Автори розглянули теоретичні та прикладні питання сучасного розуміння децентралізації в Україні, проаналізували основні тенденції реалізації децентралізаційних реформ у світі. На основі опрацьованого матеріалу запропонували концептуальні і правові засади реформування місцевого самоврядування та адміністративно-територіального устрою в умовах децентралізації повноважень в Україні. Здійснили спробу обгрунтувати доцільність змін у системі місцевого самоврядування, які сьогодні впроваджуються та передбачають реалізацію принципів субсидіарності, повсюдності місцевого самоврядування, фінансової самодостатності територіальних громад, широке застосування механізмів демократії. Автори визначили стратегічні орієнтири приведення місцевого самоврядування та територіальної організації влади у відповідність до європейських стандартів i виконання взятих державою міжнародних зобов’язань у цій сфері згідно Європейської хартії місцевого самоврядування [7].

Третю групу становлять експерти, стейкхолдери. До вивчення, обговорення окремих особливостей реформи іiі проблем реалізації, чинників, що заважали проведенню реформи, окрім науковців, долучалися й експерти, які безпосередньо так чи інакше були причетні до впровадження реформи, підготовки відповідних проектів законів, нормативно-правових документів Верховної Ради України (далі ВРУ), Кабінету Міністрів України (КМУ). Варто відмітити аналітичну доповідь, яку опублікували Я.А. Жаліло, О.В. Шевченко, В.В. Романова, що стосувалася реалізації реформи станом на 2016 рік [8]. Висвітлювали процес децентралізації також члени громадських організацій, зокрема Асоціації органів місцевого самоврядування, керівники експертних груп Громадських рад при обласних державних адміністрацій. Так, А. Кавунець, В. Дорох аналізували наявну станом на травень 2016 року нормативно-правову базу реформи, аналізували перспективні плани утворення громад в областях, складності, які вникали у громад, що добровільно об'єднувалися і потребували отримання позитивного висновку від обласних державних адміністрацій [9].

До четвертої групи належать науковці-економісти. Грунтовним дослідженням територіальних громад в умовах реформи стала монографія за редакцією В. С. Кравціва, I.3. Сторонянської. Автори дослідження розглядали особливості проходження адміністративно-фінансової децентралізації в Україні в частині аналізу цілей реформи щодо різних рівнів публічного управління та стану законодавчого забезпечення децентралізації в Україні. Аргументували необхідність саме застосування дуалістичного підходу до адміністративно-фінансової децентралізації в Україні, яким 
передбачено забезпечення спроможності адміністративно-територіальних одиниць базового рівня та утвердження державної регіональної політики, обгрунтовано можливі ризики та переваги фіскальної децентралізації на прикладі досвіду розвинених країн. Розробили методичний підхід до оцінювання ефективності механізмів фінансової децентралізації на рівні регіонів, районів, міст, територіальних громад. Запропонували методику оцінювання впливу механізмів адміністративно-фінансової децентралізації на соціально-економічний розвиток регіонів, районів, міст, територіальних громад, практична імплементація якого дозволила виявити ефективність таких механізмів 3 позиції досягнення поставлених цілей реформи. Досліджували основні тенденції та визначили ризики формування об’єднаних територіальних громад Карпатського регіону. Проаналізували сучасний інструментарій адміністративно-фінансової децентралізації в розрізі фіскальних інструментів формування доходів місцевих бюджетів, а також механізмів стимулювання економічної активності в територіальних громадах у таких сферах, як забезпечення зайнятості, ефективне управління власністю територіальних громад, просторове планування, використання природо-ресурсного потенціалу. Розглянули проблеми організації функціонування соціальної сфери в територіальних громадах, зокрема загальної середньої та дошкільної освіти, охорони здоров’я, соціального захисту населення. Досліджено ризики функціонування сучасної системи фінансового вирівнювання, що пов'язані 3 впровадженням бюджетної децентралізації [10].

Актуальні питання процесу децентралізації, відображено у посібнику колективного авторства М.Бриль, О.Врублевський, О.Данчева, А. Сеїтосманов, Е.Чубаров. Так автори дають теоретичні обгрунтування та практичні рекомендації щодо об'єднання територіальних громад. Дослідникам висвітлено права спроможної територіальної громади, наведено правові акти, що унормовують цей процес. Розкрито специфіку створення об'єднаної територіальної громади, вплив локальної ідентичності на формування згуртованості. Розглянуто питання підвищення рівня довіри між владою і громадою, процес стратегічного планування як основи сталого розвитку територій [11].

Мета статті полягас у дослідженні процесу реформування органів місцевого самоврядування в 2014-2020 роках в умовах децентралізації влади. Досягнення мети можливе внаслідок вирішення наступних завдань, зокрема:

- вивчення джерельної та нормативно правової бази досліджуваної проблематики;

- з'ясування мети реформи органів місцевого самоврядування іiі основних завдань;

- висвітлення окремих прикладів утворення, діяльності нових об’єднаннях територіальних громад, їх проблем, відповідності вимогам економічної спроможності;

- визначення перспективи подальших напрямів дослідження. 
Виклад основного матеріалу. Відповідно до розпорядження КМУ від 12 червня 2020 року, щодо визначення адміністративних центрів та затвердження територіальних громад із тоді існуючих 11250 територіальних громад було утворено 1470. 17 липня 2020 року будо прийнято постанову ВРУ №807-IX «Про утворення та ліквідацію районів» відповідно 3 адміністративної карти України зникли 490 районів та з'явилися 136 нових укрупнених районів. Вибори 25 жовтня 2020 року до місцевих рад юридично закріпили завершення реформи, що тривала п’ять років в Україні.

Мета реформи в Україні передбачала формування ефективного місцевого самоврядування та територіальної організації влади для створення і підтримки повноцінного життєвого середовища для громадян, надання високоякісних та доступних публічних послуг, становлення інститутів прямого народовладдя, узгодження інтересів держави та територіальних громад. Також реформа передбачала відповідальність органів місцевого самоврядування перед жителями - за ефективність своєї роботи, а перед державою - за їі законність [12]. Що означало, що за всі проблеми і здобутки в громаді відповідає місцева влада, яку обрали виборці громади, тобто жителі громади відповідають за розвиток території на якій вони проживають.

Реформа децентралізації дала поштовх до формування дієздатного та найбільш наближеного до громадянина інституту влади - місцевого самоврядування. Добровільне об'єднання територіальних громад дозволило новоутвореним органам місцевого самоврядування дістати відповідні повноваження та ресурси, що їх раніше мали міста обласного значення.

Інтереси громадян, які мешкають на території об'єднаної громади, представляють обраний голова, депутатський корпус та виконавчі органи ради громади, що забезпечують реалізацію наданих законом повноважень в інтересах громади. У населених пунктах, що увійшли до складу об'єднаної громади, право жителів на місцеве самоврядування та надання послуг громадянам забезпечують обрані ними старости.

Відповідно до Закону України «Про добровільне об'єднання територіальних громад» збільшення та об'єднання громад здійснювалось шляхом добровільного об'єднання з урахуванням думки громадян [13]. Обов'язковим при плануванні створення громад було визначення потенційних ресурсних можливостей громади для економічного та соціального розвитку і можливості забезпечити надання якісних послуг жителям, тобто економічної спроможності громади.

Характерно, що слово «добровільне» об'єднання в законі з'явилося із подачі народних депутатів перед самим остаточним голосуванням закону. I на наш погляд, дещо уповільнило процес об'єднання територіальних громад в Україні. Адже частина заможних громад в особі їх еліт не поспішала до об'єднання. Як приклад, можна навести громади Бориспільского, КиєвоСвятошинського та Вишгородського районів Київської області, які лише відповідно до розпорядження КМУ були утворені у 2020 році. А ні лідери заможних сільських рад, ні активні свідомі громадяни не поспішали об'єднуватися із сусідніми менш заможними населеними пунктами, вище 
зазначених районів.

За 5,5 років реформи утворено 1070 об'єднаннях територіальних громад, у які добровільно об'єдналися лише 4882 громад, що було менше половини існуючих. 3 них у 936 ОТГ відбулись перші місцеві вибори. Значна частина громад були утворені всупереч методиці формування спроможних територіальних громад [14]. Це означало, що до процесів утворення громад активно почали долучатися місцеві еліти, які таким чином намагалися відстояти свої інтереси та територіях де були розміщенні їхні об'єкти виробництва. Так наприклад, утворена у грудні 2017 році Студениківська громада Переяслав-Хмельницького району Київської області була самодостатньою, i 3 iï бюджету навіть відбувалося реверсне вилучення коштів, це вказувало на те, що громада із самого початку мала бути за чисельністю населення значно більшою. Тоді як Баришівська сільська громада, що на Київщині, утворена у 2018 році, згідно методичних розрахунків по факту «добровільності» не до отримала до свого складу кілька сільських рад, внаслідок бажання керівництва цих сіл приєднатися до сусідньої Березанської міської громади Київської області. Тому Баришівська громада протягом двох років свого існування була дотаційною. Утворені у 2019 році Ташанська та Циблівська громади Переяслав-Хмельницького району Київської області після виборів 30 червня 2019 року до 01 січня 2021 року так i не отримали обіцяного прямого фінансування із державного бюджету. Відповідно 60\% ПДФО продовжувало надходити до бюджету Переяслав-Хмельницького району, яким розпоряджалася ПереяславХмельницька районна рада та РДА при тому, що в районі було утворено 4 територіальні об'єднані громади, які фактично покривали 90\% території району. Тобто, юридично, громади не підпорядковувалися районній владі, яка втратила свій вплив на них, але протягом двох років існування в межах нових громад, районна влада продовжувала використовувати їх гроші на свій розсуд.

Протягом періоду реформи КМУ періодично перезатверджував перспективні плани формування територіальних громад в областях. Проте вже у 2020 році було урядом затверджено остаточні перспективні плани формування територій громад 24 областей, які 100\% охоплюють територію областей. Площа утворених ОТГ становить майже 47\% від загальної площі України. В ОТГ та містах обласного значення проживає понад 70\% населення України .

Відповідно до прийнятого Закону України від 16 квітня 2020 року № 562-IX «Про внесення змін до деяких законів України щодо визначення територій та адміністративних центрів територіальних громад» [15], КМУ визначено адміністративні центри та затверджено території 1470 спроможних територіальних громад до яких відбулися 25 жовтня 2020 року місцеві вибори на новій територіальній основі [16].

Утворені громади у 2016-2018 роках, окрім власної спроможності отримали від Уряду України додаткові гроші, так звані інфраструктурні субвенції. До того ж частина бюджетів обласних рад на умовах спів 
фінансування об'єктів нових громад були направлення на ремонти опорних навчальних закладів, адміністративних будівель, Центрів надання адміністративних послуг. Так завдяки програмі Підтримка Реформи децентралізації в Україні /U-LEAD 3 Свропою, що фінансувалося Свропейським Союзом, нові територіальні громади отримали 148 i 489 запланованих ЦНАпів, програма передбачала не тільки отримання сучасного обладнання, а й навчання персоналу, якого до того часу громади не мали [17].

Ефективне місцеве самоврядування та забезпечення ним поступального соціально-економічного розвитку відповідних територій супроводжувалося збільшенням ресурсної та фінансової бази. Тому із внесенням змін до Податкового та Бюджетного кодексів, від 01 січня 2015 року місцевим самоврядуванням отримано більше фінансів для підвищення економічної спроможності [18].

Об’єднані громади здобули повноваження та ресурс, які мали міста обласного значення, зокрема - зарахування до місцевих бюджетів ОТГ 60\% податку на доходи фізичних осіб на власні повноваження. Окрім того, на місцях повністю залишаються надходження від податків: єдиного, на прибуток підприємств і фінансових установ комунальної власності та податку на майно (нерухомість, земля, транспорт).

До того ж, ОТГ отримали прямі міжбюджетні відносини з державним бюджетом (до реформи прямі відносини мали лише обласні та районні бюджети, бюджети міст обласного значення), для виконання делегованих державою повноважень їм надаються відповідні трансферти (дотації, освітня та медична субвенції, субвенція на розвиток інфраструктури громад тощо). Законодавчі зміни також надали право органам місцевого самоврядування затверджувати місцеві бюджети незалежно від дати прийняття закону про Державний бюджет.

Такі покращення дали перші результати. Власні доходи місцевих бюджетів з 2014 по 2019 рік збільшилися на 200 млрд. грн. (з 68,6 млрд. грн. до 267 млрд. грн). Проте більшість лідерів громад не були готові до ефективного використання цих грошей на благо громад. Так, наприклад, Гайшинська сільська рада Переяслав-Хмельницького району Київської області, протягом 2016-2020 років на своїх рахункам станом на 01 січня кожного року мала 7 млн. грн., гроші надходили за рахунок акцизу від пального, єдиного, земельного податків. Проте у селі не було за цей період реалізовано, жодного інфраструктурного проекту. А дороги, що будувалися мали до тендерні суми. Таким чином використання коштів було не надто прозоре, відповідно до вимог законодавства, а дороги не надто широкими. 5 річне затяжне використання коштів сільською радою вказувала на відсутність необхідного професійного рівня компетенції у керівництва сільської ради. Також керівництва новоутворених громад, у 2018 році активно розпочало розміщати гроші на депозитних рахунках українських банків, що викликало певне невдоволення, як у керівництва держави так і у пересічних громадян [19; 20]. На наш погляд така ситуація була спровокована як мотивацією керівництва громад зі сторони банків, так і не 
розумінням, як використовувати гроші, які активно надходили на рахунки сільських громад. Новоутворені громади, сільські ради на територіях яких були автозаправні комплекси чи торгівельні мережі, почали активно отримувати акцизні збори з пального, тютюну, алкоголю. Проте у своїх штатах не мали ні фахівців із фінансового планування, ні спеціалістів, які б могли написати проект на співфінасування 3 бюджетами вищих рівнів чи провести тендерні закупки, адже зміни до бюджетного кодексу вимагали більшість закупівель проводити на публічних площадках Прозоро.

Об'єднані територіальні громади, крім зростання власних фінансових можливостей, у результаті децентралізації отримали й інші інструменти забезпечення економічного розвитку - здійснення зовнішніх запозичень, самостійне обрання установ 3 обслуговування коштів місцевих бюджетів відносно розвитку та власних надходжень бюджетних установ. Проте через відсутність досвіду, фахівців мало які громади активно користувалися цим фінансовим інструментом. Децентралізовано повноваження у сфері архітектурно-будівельного контролю та удосконалення містобудівного законодавства, органам місцевого самоврядування надано право самостійно визначати містобудівну політику.

Після прийняття низки законів щодо децентралізації повноважень і регулювання земельних відносин громади дістануть право розпоряджатися землями за межами населених пунктів. Проте у переважній своїй більшості нещодавно обране керівництво новоутворених громад не поспішали проводити інвентаризацію земель громади, тим самим бюджет громад продовжував недотримувати податки. Верховною Радою України прийнято закони, які надають можливість децентралізувати частину повноважень Центральних органів виконавчої влади щодо надання базових адміністративних послуг: реєстрацію нерухомості, бізнесу, місця проживання особи - передавши їх на рівень громад [10].

Напрацьовані законопроекти, покликані чітко розмежувати повноваження у сфері освіти, охорони здоров'я, дозвілля, соціальноекономічного розвитку, інфраструктури між органами місцевого самоврядування та органами виконавчої влади на кожному з територіальних рівнів адміністративно-територіального устрою держави. Проте ці ініціативи ще не отримали статусу законів.

Загалом Урядом України головними цілями реформи визначено:

1. Формування нової територіальної основу для діяльності органів влади шляхом:

визначення адміністративно-територіального устрою базового рівня для формування на новій територіальній основі спроможних територіальних громад; визначення адміністративно-територіального устрою субрегіонального (районного) рівня як територіальної основи для діяльності органів державної влади; визначення засад адміністративно-територіального устрою України, порядку створення, ліквідації, встановлення i зміни меж адміністративно-територіальних одиниць та населених пунктів відповідно до європейських стандартів; створення та адміністрування Державного реєстру 
адміністративно-територіальних одиниць та населених пунктів України в рамках виконання нової бюджетної програми «Електронне урядування у сфері розвитку громад та територій України» [12].

2. Формування ефективного місцевого самоврядування та оптимальної системи територіальної організації влади на новій територіальній основі шляхом:

закріплення реформи місцевого самоврядування та територіальної організації влади в Україні шляхом внесення відповідних змін до Конституції України; розподілу повноважень між органами місцевого самоврядування та органами виконавчої влади, в тому числі щодо повноважень територіальних органів центральних органів виконавчої влади, їх підрозділів з урахуванням принципу субсидіарності та нової територіальної основи; впровадження збалансованої бюджетної моделі надходжень та витрат органів місцевого самоврядування на виконання власних та делегованих повноважень; переформатування місцевих державних адміністрацій відповідно до нової компетенції, основними повноваженнями яких буде забезпечення законності та правопорядку, додержання прав і свобод громадян, виконання державних і регіональних програм, забезпечення координації (взаємодії) діяльності територіальних органів центральних органів виконавчої влади, здійснення адміністративного нагляду за законністю актів органів місцевого самоврядування; розвитку форм міжмуніципального співробітництва, зокрема щодо створення та діяльності міських агломерацій; вирішення питання щодо відкритості та прозорості адміністрування місцевих податків і зборів органами місцевого самоврядування; створення сприятливих правових умов для залучення жителів територіальних громад до прийняття управлінських рішень на місцях, розвиток форм місцевої демократії; створення та адміністрування Сдиного державного реєстру актів органів місцевого самоврядування в рамках виконання нової бюджетної програми «Електронне урядування у сфері розвитку громад та територій України»; створення та адміністрування Державного реєстру повноважень органів місцевого самоврядування в рамках реалізації нової бюджетної програми «Електронне урядування у сфері розвитку громад та територій України» [12].

Висновки. Реформа децентралізації в Україні активно досліджували та висвітлювали, як науковці так і експерти. Найбільш грунтовно досліджено саме тонкощі фінансової децентралізації в частині зміни напрямків надходження податків, а також юридичні аспекти пов'язані із недосконалістю українського законодавства. Загалом процес децентралізації набув значного резонансу також серед населення, адже змінилися не тільки масштаби районів, а й виникали нові адміністративні центри. Встановлено мету реформи, що полягала у двох основних цілях, які були визначені Кабінетом Міністрів України. Процес об'єднання територіальних громад був складним, довготривалим і не завжди добровільним та безболісним.

Перспективним напрямом подальшого наукового дослідження вважаємо необхідність висвітлення процесу утворення окремих громад, історії відмов iз боку центральних органів влади громадам у їх бажанні добровільного 
об'єднання. Варто також досліджувати природу, причини конфліктів, що виникали у процесі утворення громад та перших років існування нових громад.

\section{Jimepamypa:}

1. Гнидюк I.В., Гороховська Ю.І. Децентралізація в Україні: сучасний стан та перспективи розвитку. Молодий вчений. 2015. №5 (20). Частина 1, С. 108-111.

2. Тарасенко Т. Проблема децентралізації в реформуванні місцевого самоврядування в Україні, Державне управління та місцеве самоврядування. 2014. Вип. 2 (21) С. 277- 286.

3. Василенко Л., Добровінський М. Децентралізація та реформа місцевого самоврядування .Підприємство, господарство і право. 2017. №3 С. 123- 126.

4. Сгорова В.С. Процес децентралізації влади в Україні. Часопис Київського університету права . 2017/4. С. 66- 69.

5. Нікітенко Л.О., Кондратенко В.І. Процес децентралізації та зміцнення місцевого самоврядування в Україні. Науковий вісник Ужгородського національного університету. 2015. Серія Право. Випуск 32. Том 1. С. 132-136 .

6. Юркевич І. Децентралізація та реформування місцевого самоврядування в Україні. Актуальні проблеми правознавства. Конституційне право. Адміністративне право і процес. Фінансове право. Інформаційне право. Міжнародне право. 2017 . Випуск 3 (11). C.100-104

7. Лелеченко А. П., Васильєва О. І., Куйбіда В. С., Ткачук А. Ф. Місцеве самоврядування в умовах децентралізації повноважень: навч. посіб. / [А. П. Лелеченко, О. І. Васильєва, В. С. Куйбіда, А. Ф. Ткачук] - К. : - 2017. - 110 с.

8. Децентралізація влади: порядок денний на середньострокову перспективу. Аналітична доповідь. Авт.: Жаліло Я.А., Шевченко О.В., Романова В.В. та ін. Національний інститут стратегічних досліджень. - К.: 2019. - 115 с.

9. Кавунець А., Дорох В. Особливості об’єднання територіальних громад в Україні (регіональний аспект). Видання друге, доповнене. 2016.96 с.

10. Територіальні громади в умовах децентралізації: ризики та механізми розвитку: монографія / за ред. Кравціва В. С., Сторонянської І. 3. Львів: ДУ «Інститут регіональних досліджень імені М. І. Долішнього НАН України, 2020. (Серія «Проблеми регіонального розвитку»). $531 \mathrm{c}$.

11. Успішна територіальна громада: будуємо разом / Бриль М., Врублевський О., Данчева О., Сеїтосманов А., Чубаров Е. -Харків: Видавничий будинок Фактор, 2018. -128 с.

12. Реформа децентралізації. Режим доступу: https://www.kmu.gov.ua/diyalnist/reformi/efektivne-vryaduvannya/reforma-decentralizaciyi .

13. Закон України «Про добровільне об'єднання територіальних громад». Режим доступу: https://zakon.rada.gov.ua/laws/show/157-19\#Text .

14. Постанова КМУ № 214 від 8 квітня 2015 р. «Про затвердження Методики формування спроможних територіальних громад». Режим доступу: https://zakon.rada.gov.ua/laws/show/214-2015-\%D0\%BF\#Text .

15. Закону України від 16.04.2020 № 562-IX «Про внесення змін до деяких законів України щодо визначення територій та адміністративних центрів територіальних громад». Режим доступу: https://zakon.rada.gov.ua/laws/show/562-20\#Text .

16. Постанова Верховної ради «Про утворення та ліквідацію районів» 17 липня 2020 року № 807-IX. Режим доступу: https://zakon.rada.gov.ua/laws/show/807-20\#Text .

17. Покращення якості надання адміністративних послуг для населення / Підтримка Реформи децентралізації в Україні /U-LEAD. Режим доступу: https://tsnap.ulead.org.ua/

18. Закон України «Про внесення змін до Податкового кодексу України та деяких законодавчих актів України щодо забезпечення збалансованості бюджетних надходжень у 
2016 році» 24 грудня 2015 року № 909-VIII. Режим доступу: https://zakon.rada.gov.ua/laws/show/909-19\#Text .

19. Оголошення. Режим доступу: http://studenykivska.gromada.org.ua/news/1558334108/

20. Про кошти громад на депозитах та про трирічне планування місцевих бюджетів, - інтерв'ю з заступником міністра фінансів. [Електронний ресурс]. - Режим доступу: https://decentralization.gov.ua/news/6496 .

21. Висновок Конституційного Суду України у справі за зверненням Верховної Ради України про надання висновку щодо відповідності законопроекту про внесення змін до Конституції України щодо децентралізації влади вимогам статей 157 і 158 Конституції України. Справа № 1-18/2015 30 липня 2015 року № 2-в/2015. Режим доступу: https://zakon.rada.gov.ua/laws/show/v002v710-15\#Text .

22. Закон України «Про співробітництво територіальних громад». Режим доступу: https://zakon.rada.gov.ua/laws/show/1508-18\#Text .

23. Особиста Фейсбук сторінка народного депугата України Віталія Безгіна 9 скликання . Режим доступу: https://www.facebook.com/photo?fbid=2732546080331891\&set=a.1470655633187615 .

24. Про схвалення Концепції реформування місцевого самоврядування та територіальної організації влади в Україні: розпорядження Кабінету Міністрів України від 1 квітня 2014 року № 333-р [Електронний ресурс]. - Режим доступу: https://zakon.rada.gov.ua/laws/show/333-2014-\%D1\%80\#Text

25. Як ОТГ Херсонщини кадровий голод «вгамовують» [Електронний ресурс]. Режим доступу: https://decentralization.gov.ua/news/8178.

\section{References:}

1. Hnydiuk, I.V., Horokhovska, Yu.I. (2015). Detsentralizatsiia v Ukraini: suchasnyi stan ta perspektyvy rozvytku [Decentralization in Ukraine: current state and development prospects]. Molodyi vchenyi - Young scientist, 5(20), 1, 108-111 [in Ukrainian].

2. Tarasenko, T. (2014). Problema detsentralizatsii v reformuvanni mistsevoho samovriaduvannia $\mathrm{v}$ Ukraini [The problem of decentralization in the reform of local selfgovernment in Ukraine]. Derzhavne upravlinnia ta mistseve samovriaduvannia - Public administration and local self-government, 2(21), 277-286 [in Ukrainian].

3. Vasylenko, L., Dobrovinskyi, M. (2017). Detsentralizatsiia ta reforma mistsevoho samovriaduvannia [Decentralization and reform of local self-government]. Pidpryiemstvo, hospodarstvo i pravo - Enterprise, economy and law, 3, 123-126 [in Ukrainian].

4. Yehorova, V.S. (2017). Protses detsentralizatsii vlady v Ukraini [The process of decentralization of power in Ukraine]. Chasopys Kyivskoho universytetu prava-Journal of Kyiv University of Law, 4, 66-69 [in Ukrainian].

5. Nikitenko, L.O., Kondratenko, V.I. (2015). Protses detsentralizatsii ta zmitsnennia mistsevoho samovriaduvannia $\mathrm{v}$ Ukraini [The process of decentralization and strengthening of local self-government in Ukraine]. Naukovyi visnyk Uzhhorodskoho natsionalnoho universytetu. Seriia Pravo - Scientific Bulletin of Uzhhorod National University, 32(1), 132-136 [in Ukrainian].

6. Yurkevych, I. (2017). Detsentralizatsiia ta reformuvannia mistsevoho samovriaduvannia $\mathrm{v}$ Ukraini [Decentralization and reform of local self-government in Ukraine]. Aktualni problemy pravoznavstva - Actual problems of Law, 3(11), 100-104 [in Ukrainian].

7. Lelechenko, A.P., Vasylieva, O.I., Kuibida, V.S., Tkachuk, A.F. (2017). Mistseve samovriaduvannia $v$ umovakh detsentralizatsii povnovazhen [Local government in terms of decentralization of powers]. Kyiv [in Ukrainian].

8. Zhalilo, Ya.A., Shevchenko, O.V., Romanova, V.V., et al. (2019). Detsentralizatsiia vlady: poriadok dennyi na serednostrokovu perspektyvu [Decentralization of power: an agenda for the medium term]. Kyiv: Natsionalnyi instytut stratehichnykh doslidzhen [in Ukrainian].

9. Kavunets, A., Dorokh, V. (2016). Osoblyvosti obiednannia terytorialnykh hromad v 
Ukraini (rehionalnyi aspekt) [Features of the association of territorial communities in Ukraine (regional aspect)]. (2nd ed.). Vinnytsia: TOV "Pres Korporeishn Limited" [in Ukrainian].

10. Kravtsiv, V. S., Storonianska, I. Z. (Eds.). (2020). Terytorialni hromady v umovakh detsentralizatsii: ryzyky ta mekhanizmy rozvytku [Territorial communities in terms of decentralization: risks and mechanisms of development]. Lviv: DU «Instytut rehionalnykh doslidzhen imeni M. I. Dolishnoho NAN Ukrainy [in Ukrainian].

11. Bryl, M., Vrublevskyi, O., Dancheva, O., Seitosmanov, A., Chubarov, E. (2018). Uspishna terytorialna hromada: buduiemo razom [Successful territorial community: building together]. Kharkiv: Vydavnychyi budynok Faktor [in Ukrainian].

12. Reforma detsentralizatsii [Decentralization reform]. www.kmu.gov.ua. Retrieved from https://www.kmu.gov.ua/diyalnist/reformi/efektivne-vryaduvannya/reforma-decentralizaciyi [in Ukrainian].

13. Zakon Ukrainy «Pro dobrovilne obiednannia terytorialnykh hromad» : vid 5 liutoho 2015 roku № 157-VIII [Law of Ukraine "On Voluntary Association of Territorial Communities" from February 5 2015, № 157-VIII]. zakon.rada.gov.ua. Retrieved from https://zakon.rada.gov.ua/laws/show/157-19\#Text [in Ukrainian].

14. Postanova KMU «Pro zatverdzhennia Metodyky formuvannia spromozhnykh terytorialnykh hromad» : vid 8 kvitnia 2015 r., № 214 [Resolution of the Cabinet of Ministers of Ukraine "On approval of the Methodology for the formation of affluent territorial communities" from April 8 2015, № 214]. zakon.rada.gov.ua. Retrieved from https://zakon.rada.gov.ua/laws/show/214-2015-\%D0\%BF\#Text [in Ukrainian].

15. Zakonu Ukrainy «Pro vnesennia zmin do deiakykh zakoniv Ukrainy shchodo vyznachennia terytorii ta administratyvnykh tsentriv terytorialnykh hromad» : vid 16.04.2020, № 562-IX [Law of Ukraine "On Amendments to Certain Laws of Ukraine Concerning the Definition of Territories and Administrative Centers of Territorial Communities" from 16.04.2020, № 562-IX]. zakon.rada.gov.ua. Retrieved from https://zakon.rada.gov.ua/laws/show/562-20\#Text [in Ukrainian].

16. Postanova Verkhovnoi rady «Pro utvorennia ta likvidatsiiu raioniv» : vid 17 lypnia 2020 roku, № 807-IX [Resolution of the Verkhovna Rada "On the formation and liquidation of districts" from July 17 2020, № 807-IX]. zakon.rada.gov.ua. Retrieved from https://zakon.rada.gov.ua/laws/show/807-20\#Text [in Ukrainian].

17. U-LEAD z Yevropoiu. Napriam z pokrashchennia yakosti nadannia administratyvnykh posluh dlia naselennia [U-LEAD with Europe. Direction to improve the quality of administrative services for the population]. tsnap.ulead.org.ua. Retrieved from https://tsnap.ulead.org.ua/ [in Ukrainian].

18. Zakon Ukrainy «Pro vnesennia zmin do Podatkovoho kodeksu Ukrainy ta deiakykh zakonodavchykh aktiv Ukrainy shchodo zabezpechennia zbalansovanosti biudzhetnykh nadkhodzhen u 2016 rotsi» : vid 24 hrudnia 2015 roku, № 909-VIII [Law of Ukraine “On Amendments to the Tax Code of Ukraine and Certain Legislative Acts of Ukraine Concerning Ensuring Balance of Budget Revenues in 2016" from December 24 2015, № 909-VIII]. zakon.rada.gov.ua. Retrieved from https://zakon.rada.gov.ua/laws/show/909-19\#Text [in Ukrainian].

19. Shche raz shchodo pytannia funktsionuvannia viddilennia Oshchadbanku [Again on the functioning of the Oshchadbank Branch]. (2019). studenykivska.gromada.org.ua. Retrieved from http://studenykivska.gromada.org.ua/news/1558334108/ [in Ukrainian].

20. Pro koshty hromad na depozytakh ta pro tryrichne planuvannia mistsevykh biudzhetiv, - interviu z zastupnykom ministra finansiv [On community funds on deposits and about threeyear planning of local budgets - an interview with the Deputy Minister of Finance]. decentralization.gov.ua. Retrieved from https://decentralization.gov.ua/news/6496 [in Ukrainian].

21. Vysnovok Konstytutsiinoho Sudu Ukrainy u spravi za zvernenniam Verkhovnoi Rady Ukrainy pro nadannia vysnovku shchodo vidpovidnosti zakonoproektu pro vnesennia zmin do 
Konstytutsii Ukrainy shchodo detsentralizatsii vlady vymoham statei 157 i 158 Konstytutsii Ukrainy. Sprava № 1-18/2015 vid 30 lypnia 2015 roku, № 2-v/2015 [Opinion of the Constitutional Court of Ukraine in the case at the request of the Verkhovna Rada of Ukraine to issue an opinion on the compliance of the draft law on amendments to the Constitution of Ukraine on decentralization of power with the requirements of Articles 157 and 158 of the Constitution of Ukraine. Case № 1-18/2015 July 30, 2015 № 2-v/2015]. zakon.rada.gov.ua. Retrieved from https://zakon.rada.gov.ua/laws/show/v002v710-15\#Text [in Ukrainian].

22. Zakon Ukrainy «Pro spivrobitnytstvo terytorialnykh hromad» : vid 17 chervnia 2014 roku, № 1508-VII [Law of Ukraine "On Cooperation of Territorial Communities" from June 17 2014, № 1508-VII]. zakon.rada.gov.ua. Retrieved from https://zakon.rada.gov.ua/laws/show/1508-18\#Text [in Ukrainian].

23. Bezgin, V. (2020). Dumaiu, shcho sohodni harnyi den, shchob pidbyty promizhni detsentralizatsiini pidsumky nashoi kadentsii ... [I think that today is a good day to sum up the intermediate decentralization results of our cadence ...]. www.facebook.com. Retrieved from https://www.facebook.com/BezginVitalik/posts/2732546133665219 [in Ukrainian].

24. Rozporiadzhennia Kabinetu Ministriv Ukrainy "Pro skhvalennia Kontseptsii reformuvannia mistsevoho samovriaduvannia ta terytorialnoi orhanizatsii vlady v Ukraini" : vid 1 kvitnia 2014 roku, № 333-r [Order of the Cabinet of Ministers of Ukraine "On approval of the Concept of reforming local self-government and territorial organization of power in Ukraine" from April 1 2014, № 333-r]. zakon.rada.gov.ua. Retrieved from https://zakon.rada.gov.ua/laws/show/333-2014-\%D1\%80\#Text [in Ukrainian]

25. Yak OTH Khersonshchyny kadrovyi holod «vhamovuiut»[AHs of Kherson Oblast "appease" personnel hunger]. (2018). decentralization.gov.ua. Retrieved from https://decentralization.gov.ua/news/8178 [in Ukrainian]. 